\title{
ある酒造業経営者の理想と現実
}

\author{
近促法による構造改善計画にさきがけて未納税酒の共同製造を熱心に \\ 推進された筆者に理想と現実とをむすびつけるための御意見を自由にの \\ ベていただいた。
}

\author{
西の誉銘 䤑（株） \\ 伊藤田 力
}

若い経営者欄に何か自由な立場で，之の御依頼があり， 常々本協会誌を通じ有益な資料を戴くままにしているだ けに，むげにおことわりも出来ず，そらかといって御期 待に添学るようなことが書けるか, 自信もないまま筆 を取った次第である。若い経営者が，平素見たり聴いた り思ったり感じたりしたことをそそのまま述べて見た い。

\section{1. 清酒の販売集中度について}

まず第 1 の販売集中度のことであるが，ここ数年の間 に加速度的に起っている現象で, 単一の銘柄で年間を集 計して 65 万石を販売し，な担旦つ数年を経ずして 100 万石販売になって行くといら勢いで, 年々伸びているも のがみられる。この最高肘売銘柄を中心に市場での販売 競争は激化の一途を辿っている。一方清酒の消費の伸び 率は, 年間 $3 \sim 4 \%$ 程度で, 成長型から頭打ち型の商品 に転向の傾向をみせているといらことは, 多数の弱小経 営者にとって, 市販酒の販売に何等かの形で影響なしに はすまされない筈である。さらに悪いことは全国年間消 費実績は昭和 47 年 4 月〜昭和 48 年 3 月で 895 万石程 度なのに生産は同じ期間中で 980 万石になっており, 持 ち越し在庫は益々增加するばかりである。したがって自 由競争下では，市場が乱れる条件があまりにも整い寸ぎ ているといって良いのではないだろらか。現在では販売 数量上位銘柄を上から 150 を集計すると，国内年間消費 の 895 万石の $70 \%$ 以上を占めてしまうことになる。し たがって上位銘柄 150 を除く残りの 3 千数百の弱小銘柄 はさらにきびしい市場での競争なしに販売出来る訳がな いのである。このことは清酒の販売市況は正に過当な競 争の渦中にあるといってもよいのではないか。

もう一つの悪条件は清酒の消費数量の動きが毎年 12
月に集中寸る傾向を示し，6月，7月，8月の夏期の動 きが少なくなって行くように感じられることである。す なわち肘売競争に時間の例約が加わると, さらに競争は 激しくなり，人手不足も加わ；て経営者にかか心て来る 荷物はますます重くなるばかりだと感じてくる。それな ら何故こういらようなことになったのだろらか。受けと め方にもよるが，その1は戦後の経済成長に伴ら国内す べての生産業の成長が, 余りにも急激に行なわれていっ たためで不可抗力的とい兄るかもしれない。その 2 は清 酒の製造原料である米が食糧管理法下のものだけに生産 もまた統制下に置かれざるを得なかったにもかかわら ず，販売は自由化の方向に移行せざるを得ない上らな社 会状勢にあったこと。その 3 は企業の立場からは大量生 産, 大量販売機構を取らねば経営に発生してくる不如意 な諸条件を消化，吸収する道が他になかったこと。その 4 は戦後の経営は少数の経営者を除いては自己資金経営 から借入資本経営に移行したこと。その第 4 は今日業界 の問題になっている転廃業が容易に出来にくい原因にも なっていると思われるし, また適正生産に向っても簡単 に一年休造するようなことが出来にくい原因になってい るとも思われる。

\section{2. 全酒類の年間消費の中にしめる 清酒の位置}

およそ経営者である限り自らが行なっている事業が社 会のどの位置で寄与しているかを自覚し, 確認すること が問題である。その上で行政に求めることは求め, また 社会に求めることは求めるのでなければ仕事にならない と考えている。社会の構造に変化が起れば，国民の赀好 の傾向にも変化のあることは当然で, 戦前は酒といら言 葉は清酒の代名詞であったように, 清酒は国民のアルコ 
ール飲料の大部分を占めていたが，今日では全酒類消費 の中で清酒は $30 \%$ 以下に落ちている。

したがって重要なことは戦前の酒稅即国庫の歳入財源 の中でも重要な位置にあり，またこのための法律である 酒税法の如きも清酒のための法律のようなものであった が，今日ではビールが 1,800 万石と第一位の消費量をし めす時代になっているのである。そしててまた大蔵省の歳 入源から清酒税収が何処にあるか探して見ても清酒の国 内全産業の中の地位が大きく変化していることを確認せ ねばならない。

このように述べると，如何にも清酒業は肩身の狭い産 業かのよらである。しかし忘れてならないことは，国内 で 890 万石からの清酒が年間確実に消費されており，微 細ではあるが需要の伸びを持っている産業であるという こ上は間違いない実態であり，むしろこの起点の上に立 って今後を展望すべきではあるまいかと思われる。

\section{3. 酒税納付額の集中度}

第 2 の項で述べたように上位 150 の銘柄が全清酒の年 間課税移出数量の $70 \%$ を占めているといらことは，酒 税もまたこれ等 150 の経営責任者汇よって納められてい るといらことで，残りの 3 千数百の清酒製造業者の全部 で清酒の全酒税総額の $30 \%$ を納めていることに思いを めぐらすと, 嫌が応でも大多数の経営者は弱小の納税者 であるといらことである。ここで政治の問題を次のよ らに感じるのである。かつては国の非常時には企業整備 が行なわれ，残った生産者がこの国民需要に応えて清酒 の生産業を営み，酒税を急りなく納めて今日までやって きながら, 酒税の奇与率が悪いからといってこれ等の経 営者に自己の事業に対する去就を問うような政治にな っては, どうも何か歯切れの悪いものを感ずるものがあ る。勿論政治といらものは時と, 処讁合して行なわれ ねばならないことは理解出来るが, そらかといって歴史 の因果関係を無視しては文化の後退を嘆くしかないもの と思う。

\section{4. 多数弱小経営者の今後の方向}

この問題について考光る前に各々の経営者をその立場 から分類して見ると, 次の 3 つの組になると思う。すな わち（1現在清酒製造業をやっているが，こんなにむず かしい経営条件でこの事業に執着するよりも自己の能力 に適した他の企業に自信をるって転業することの出来る 経営者。環境からしても, 自己の能力から考えても今日 まで長い年月やってきた清酒の製造業が，自己に最も適 した事業であってこの事業の他に希望をもってやる事業 は自分には全然ない。したがってどんなに困難があろう
と生涯を清酒の製造業にかけて行こらと心にきめた経営 者。現実は経営の責任を取ってはいるが，このままこ の事業に希望を持って前進することにも自信がなく，そ らかといって転業して他の事業に取り付く自信も希望も 持てないが，行けるところまで行こうと思っている経営 者。このように分けて見ると(1)経営者は業界の努力に 基づく清酒製造業安定に関する特別法によって, 転廃給 付金を受けることによって希望が満たされると思われる。 次に可の経営者は清酒製造業の構造改善計画の中に飛び 込んで，自己の道をひらいて行かねばならない立場の経 営者と思われる。この組には斯く申寸私もその一員であ

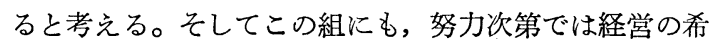
望は十分あると感じている。問題はの経営者の皆さん のことである。この組の人が最も悩みも多く、日常生活 も決して楽しくなく，そのらちに何とかなるのではない かといら気持ちは十分理解出来るが，行政の立場にある 方や組合を通じて業界の世話をする方，また，将来の見 通しを求めて経営の舵を取ろらとする経営者にとって, このよらな考方に困惑が残ると思われる。今日中央会 で適正生産に正面から協力する経営者に特別見舞金の給 付を決定したのもこの問題に多分に関連していると思 う。行政的に冷い風でなく，暖い風でこの問題の取扱い に最大の努力が払われていることに敬意を感じているも のであるが，しかし清酒製造業自体が社会の発展に貢献 する企業であるとともに, 他面自己の生業であり家業で もあるのであるからそれを善処し, 解決して行くことは 何処までも自己の責任であるべきだと考える。この問題 を概括すると上記のように 3 分類はしたものの実際には 全員㥂互いに足を引張りあって, 明確な方針決定のため の力を失っているのではないかと思われる。何故ならこ んなに流動する社会では困難を打開する合理的な判断を する前に，「何はともあれ肘売增進だけはやって置かね ば明日の日が来ない」といら感覚になり勝であるから， 勢い肘売競争に突進し, こんな方向に進む程加速度が加 わり, 過当競争になり, 次第に取り返しのつかない経営 状態に陥るのが現実と思われる。勿論なかには諎種の企 業を兼業して清酒外の企業利益で清酒製造業を助けてい る場合もあり, また他の企業に重点を置き, 清酒の利益 を度外視して単に廃業は面目ないことたかからしたくない と考兵ている経営者もあろう。それ等が，互いに集合し た複雑な業界が，今日の清酒業界と思われる。この問題 が経営責任者を最も悩ましていることである。何故なら 経営の責任者は自己の生産商品を消費する消費の動向が どらであるか, 将来どらなって行くか, 同業者の動向は どらであるかについて考光, 将来の見通しを求めて経営 の舵を取ららとするのが常識であるが，この常識に明確 
な答えが出てこないのが今日の業界の最も大きい悩みだ と考える。

\section{5. 清酒の販売市場における取引価格の問題}

一長い年月にわたってマル公すなわち公定価格といら官 制価格の商習慣に市場はならされている。すなわち生産 者の適正利潤と卸業・小売業の適正利潤から計算された 小壳価格が，そのまま消費者に通用した習慣がマル公制 度のなくなった今日でも,なおその余韻を残し，取引が行 なわれていることが私は問題に思うのである。符款が撤 廃され，業界は生販三譜が笑質的には生販二層にならね ばならないものか，現実には生販三層意識からまだ抜け られない状態にあるといえる。すなわら商業上の卸機能 とか小売機能がのこっており, 消費者が小売店で購入す る酒は小売価格といら標準価格にしばられていて，その 店で一本買らも百本買うも同じで，この小売価格が基準 となっている。もっと具体的にいえば, 日に千本も消費 する料飲店も小売販売価格が基準で取引がされていなが ら，小売店が仕入れに買取る同じ千本の酒の価格は卸価 格仕入れが出来る。すなわち消費者の大量買取と僅少買 取りの品には価格の差の表現がないということである。 この問題について特に申したいことは消費者にもっと解 り易い価格の表示が望ましいといらことである。消費者 が小売店で一本買ら時と，まとめて百本買う時とでは違 った值段が表示されてしかるべきではないだろうか。現 状のままだと, 卸店の売場とか生座者の店頭に, それぞ れ異った価格があるべきだと消費者の方から聞かれるよ らな時が来ると思われるのである。人口密集都市で業務 用の酒の取り引きに種々様々の条件のあることが, 取引 流通をむずかしいものにしていると私は感じているもの である。

\section{6. 消費者の嗜好の動向}

前に述べたように清酒の年間の消費量は 895 万石で毎 年 3\% 4\% は増加しているが，その内容をみると特級 ・一級の消費が異状に増加し，二級酒の消費が㟻減の傾 向を示していることが特復である。数年前までは 2 級酒 が $60 \%$ 以上であったものが今日では 2 級酒が全清酒の $47.5 \%$ で特一級が $52.5 \%$ といら姿に変っている。地域 的な人口構成の変化を考えるなら, 大都市では特一級の 消費が $80 \%$ 以上のところもあるとのことである。酒税 収入が毎年子算より多いのは，この間のことを説明して いると思う。これは消費する国民の所得の増加にもその 原因の一端があるが，嗜好品であるだけに所得が増加す れば消費の物品も高級化すると思うと, 清酒についても もっと良い酒を造りなさいと消費者から呼びかけられて
いるのではないかとも思われるのである。一方で物価を あげてはいけない，他方では良いものさ造れば価格は 高すぎるとはいわないという消費者の声を，どう受けと めて今後の経営を進めるべきか考える特にきているよう である。

\section{7. 清酒の生産構造について}

中央会の構造改善計画樹立の時かと記憶しているが， 近代化促進法の指定業種維持のためにも，また清酒製造 業安定に関する特別法の成立のためにも，この計画によ って業界の誠意を示すべきであるといら考えがあったと 思ら。この構造改善計画が執行されて 5 年目，今日なお 清酒業の安定が得られないのはどらしたことだろうか。 計画に身の入れ方が足らなかったのだろらか。それとも 計画の内容がまとをはずしていたのだろうか。しかし， 今日ではそんなことよりも適正生産による市場安定が最 大急務とされている。今日ほど機械化の進んだ，他産業 とならんで清酒製造業の構造を变えて，より経営を優秀 にする等ということが，容易なわざでない時はない。私 の如きも，3年間もこの問題ばかり研究し続けてきた思 い出がある。前進的効果を求めた計画ともなれば，各々 立場によって受けと女方はいろいろであると思うが，少 なくとも 2 か年位の期間をかけて真剣に取り組まない限 り, 成果の得られる改善は出来ないと思っている。それ 程複雑でもあり，条件が多いことを感じている。例えば 製造原価を計算してみると，工場が償却済みになってい るか, 新改築費を含めて計算すると, 原酒の価格は今日 の清酒の販売洒格を上回る数字が出て来たりする。 さて今日, 全国の清酒製造業者の工場生産能力は 1,000 万石之伺二ており，そして $47 \mathrm{BY}$ の生産は市肘酒換算 で 980 万石であって, 結局工場設備はまにあっているこ とになり，生産構造の何処を変えねばならないのかとの 問いも出ることでだろう。しかし，(1)販売集中度の変化 にともない自製酒の増産を求められたが，醸造権を買っ たり，地価の高騰を考えると，自製酒生産工場を新規拡 充することでは経済的な生産ができないこと。(2)安定し た末納税酒取引が可能になったのは良いが，未納税酒を 供給する工場つ製造経費が安定しない限り，取引価格の 点で条件が合わないできしむ不安があったこと等，この 辺に構造改善の要求が残されているように思われる。し たがって問題は償却済の工場を新改築しても, 続けて経 営が成りたって行けるような設備投資はどれほどである べきか，また製造数量の賛模はどれだけのものであれば 良いかという問いに変ってくる。私の経験から概念的に 申して見市すと 1 万石の製造賛模の工場で設備費の総て が 7,000 万円〜 8,000 万円の範囲で醇造を行なうことが 
出来るなら，今日の時点では経営が成り立つと思われ る。勿論この場合は全量未納税酒として販売先が確実で あるといらことが前提である。この考方方は未納税酒を 買付ける相手方と共存し得る道を求めてのことである。 勿論内容は簡単ではない。製造設備の組み合せ方やそこ に働く人の陣容の整備等が問題である。というのも工場 従業員の身分の安定のためにまず長期間の醇造を行な い, 年間雇用の型を取らねばならない。設備の充実によ り, 働く者に満足感を与えなければ定着度が落ちて行く 等の配虑が求められるからである。生産構造のらえで今 後販売集中度の変化にともない, 販売上位の経営者の工 場は共同瓶詰工場化して行き, 未納税酒供給工場は原酒 の生産溥門化して行くべきであるとの見解をもって いる。どうあるべきかの理想でなくて，そうならざるを 得ない環境であると考兄る。

\section{8. 製造工場の人間関係}

昔のように杜氏が一組の陣容を持って 1 酒造期間を請 け負った時代とことなり, 醸造労務が機械設備を動かす エネルギーにかわり,この機械を使う人の技術能力に依 存する率が日を追って高くなってきた。労衝力の内容が 大きく変化してきた今日, 特にこの問題を取りあげたの は次の理由に基づくものである。微生物の培養によって 艮い酒を造るという一つの目的に従って多くの人々が共 同して作業し,目的を果たそうとする時,この作業に種々 の尃門的な機峨が使用されるといらことになると，とも すると機峨を上手に使用しようといらことに精一杯で, 肝腎の最終目的である作業の総合成果の目標が何処にあ るかぼけてくる恐れを感ずるものである。重ねていらな ら, 何処まで機械が導入されようと, 酒を造る限りにお いては各部門が一つの目的に統合される人間関係にあら ねば，その目的は達せられないということで，この意味 からは昔の杜氏を中心とした人間関係の方が遙かに目的 にかなったものであったと思うのである。したがってい かに機械工学が工場に入ってきて, 電気とかボイラーと かの専門家が働こうと, 人間関係のつながりや目的の中 心を失ってはならないと思うものである。

さきに述べたように今日ビールの国内消費は 1,800 万 石, ウィスキーが 85 万石におよび, その他ブランデーや ワイン等各種の酒が消費されているが, 消費の全体の傾 问は高級品に移行している。清酒も特級, 一級が每年増 加の方向をたどっている。貿易の自由化に伴って外国の 酒もかなり輸入されている今日, 清酒は現況で良いのか といら声がきかれる。これ程外国の酒が国内で消費され ているのであるから日本の清酒もどんどん外国で消費し ていただいて良いのではあるまいか。そのためには長期
䝪蔵のきく酒が必要とあればその方向の技術の開発が当 然要請されると思うのである。また国内需要にしても特 級, 一級, 二級の三種類の清酒に消費が定着してしまっ て, どうも超特級とか手づくりの秘藏酒といって見ても 消費がついて来ないららみがある。この原因についても 追求されるべきではないだろらか。私の感じていること は, 何分にも原料が国民主食の米であり，法の管理下に あるため, 種々の学術研究による新製品の開発に制約が あるためではないかと思ったこともあったが，今日では 学術研究のために少し位米が無駄になっても, 技術の進 歩や製品の開発を犠性にすべき時ではないと私は思って いる。もっと多種多様の清酒を消費者の前にならべて, 消費者の好及を求める機会を生産者が持つべきではない だろらか。そのためには税法上には級別があっても，表 示の級別をなくする必要もあると思う。例宎ばブランデ 一ではナポレオンが特級か一級かを意識されることなく 消費されているのである。またこの問題に関連して, 品 評会の運用についても考光ねばならないものがある。吟 醇酒の品評会を無意味とはいわないが，何時までも同じ ことを繰り返す時代ではないし，その目的とするもの が，実質的に工場のもろ及製造技術の向上につながらな くなってしまった恐れを感じているのが卒直な私の意見 である。これからは例えば有能な消費者代表を審査員に 加劣て市販酒の品評会をするのも一案ではないだろう か。何れにしても経営者全員, 業界関係者を挙げて洗脸 の時にきているともいえるのではないだろらか。

\section{9. 経営者の理想と現実}

経営者は常に環境の諸条件を組合せて合理性を追求し てやまない。したがってそこには理想が生れても来るわ けである。合理性の追求の中から経営目標がたち, その 先端には理想があるわけであるが，環境の諸条件の読及 が足らなかった場合には，目標を持って進儿でもなかな かそこに到達出来ないものである。今日の私共の咊境は (1)借入資本で経営をしていること, (2)大量販売, 大量生 産を行なわない限り, 毎日発生する諸問題の処理が出来 なくなっている。もしそうでないなら，ささやかに自己 資本経営を行ならかどちらかである。しかし，どうもが いて見ても，環境の変化を完全分析して進んで見ても，現 実からは別の答えがかえってくるものであることを，業 界最近 10 年の歩みを振り返って見て感ずるものである。 近代化の共同瓶詰はどらなって行くのか, 集約製造から ぞんな答えを引き出すか，現実からどんな答えがかえっ てくるか, 注意深く経営の舵を取っていか权ばならない と思うのである。 


\section{0. 酒造組合のあり方}

今日こんなに多くの未解決の問題を抱えていることに は酒造組合の運営のあり方にも多分関係があると思わ れる。およそどの業種の同業組合であろうと, 組合に集 ってお互いに話しあうことの前提条件は, 組合員の利益 が共通し，その利益をまもるためであり，敵味方とか與 越同舟のような䨌囲気では組合会合は成り立たない。 3,000 有余の清酒の経営者が一堂に集ったところで, 利害が対立し, 共存等の論議は百日続けても答光は出な いのではないだろらか。こんな結果にならないよらな組 合のあり方, 組織のつくり方があるのではないだろらか。 今後組合といらものが必要である限り,このことを忘れ
てはならないと思うし，組合は免許者という特権階級の 社交の場所でない限り, お互い意義のある姿を求めて 止まない。

\section{おわりに}

はじめにおことわりしたように，私の思いつきや感想 をそのまま述べたものであるが，清酒の社会的需要にた いする供給者の立場でいる経営者が，今後どんな姿勢で 時局に立ち向うべきかについて，いろいろの人の意見発 表を求めて, 今後の道を見出して行くことも, 意義のあ ることかと存じ，思見を述へ，貴重な本紙面を埋めたこ とをお詫び申したい。 